\title{
Fontanus Publications
}

\author{
FONTANUS (journal)
}

v.1 1988

v. $2 \quad 1989$

v.3 1990

v.4 1991

v.5 1992 Montreal 350th Anniversary Issue

v.6 1993 Redpath Issue

v.7 1994 Stephen Leacock Issue

v. 81995 Women in the University Issue

v.9 1996 McGill 175th Anniversary Issue

v.10 1998 Rutherford Centenary Issue

\section{FONTANUS MONOGRAPH SERIES}

I Adam Gacek, Arabic Manuscripts in the Libraries of McGill University, Union Catalogue, 1991

II Calvin Evans, Sõren Kierkegaard Bibliographies: Remnants 1944-1980 and Multi-Media, 1925-1991, 1993

III Barbara Lawson, Collected Curios: Missionary Tales from the South Seas, 1994

IV John Hobbins, On the Edge of Greatness: The Diaries of John Humphrey, First Director of the United Nations Division of Human Rights, Vol. 1, 1948-1949, 1994

V Max Dunbar, Essays from a Life: Scotland, Canada, Greenland, Denmark, 1995

VI Alberto Pérez-Gómez and Louise Pelletier, Anamorphosis: An Annotated Bibliography with Special Reference to Architectural Representation, 1995

VII Adam Gacek, Arabic Lithographed Books in the Islamic Studies Library, McGill University, Descriptive Catalogue, 1996

VIII Irena Žantovská Murray, Sources in Iconography in the Blackader-Lauterman Library of Architecture and Art, McGill University, An Annotated Bibliography, 1996

IX John Hobbins, On the Edge of Greatness: The Diaries of John Humphrey, First Director of the United Nations Division of Human Rights, Vol. 2, 1950-1951, 1996

X Joan C. Bevan and Maria A. Pacelli, The Quintessential Canadian Anaesthetist: Wesley Bourne. A Retrospective on the Foundations of McGill Anesthesia, 1996

XI Goldie Sigal, A Garment Worker's Legacy: The Joe Fishstein Collection of Yiddish Poetry, 1998

XII John Hobbins, On the Edge of Greatness: The Diaries of John Humphrey, First Director of the United Nations Division of Human Rights, Vol. 3, 1952-1957, 1998

Orders may be placed at:

Marketing Department

McGill-Queen's University Press

3430 McTavish Street

Montreal QC

Canada H3A 1X9 
